\title{
ORGANIZATIONAL MECHANISM OF RURAL AREAS DEVELOPMENT SUSTAINABILITY
}

Eglė ŠTAREIKĖ, Business and Rural Development Management Institute, Aleksandras Stulginskis University, Universiteto g. 10, Akademija, Kauno raj., LT-53361, Lithuania, egle.stareike@gmail.com

\begin{abstract}
In this research organizational mechanism is analysed through the approach to the system of integrated control of the open system of social and economic integration (based on the interests of the stakeholders and interdepartmental cooperation) in the rural areas, where the stakeholders formulate the common objectives of the sustainable development of the rural areas. Aim of the research - to substantiate the conceptual organizational mechanism of development in rural areas, where one of the most important factors with the strongest effect on functionality, i.e. the driving force, is institutional environment of the region. The aim of the research was achieved using the following methods: logical, abstraction, comparison, content analysis, collation. The results of the research revealed, that organizational mechanism of rural areas development is advisable to analyse as a particular organizational form, where functions and activity processes are connected to each other, creating the following chain: aim - sustainable development of rural areas - functions of rural areas - process - preparation and implementation integrated development strategies of the rural areas - result - social welfare. The exceptional feature of the organizational mechanism is the stakeholders (subjects) and their actions. Stakeholders perform certain roles, which affect the change of environment, in seeking the specific result. Stakeholders with a specific aim seek results by performing respective functions and processes. In the organizational mechanism of rural areas development stakeholders affect the pursuit of the organizational mechanism's aims.
\end{abstract}

Keywords: organization, mechanism, stakeholders, rural development, sustainable development.

JEL classification: I31, L20, R58

\section{INTRODUCTION}

In this research attention is paid to analysis of organizational mechanism, in order to investigate the causal elements of organizational mechanism elements and processes together with relations among them while seeking sustainable development in rural areas. The main goals of the research of organizations are to explain how certain events take place or how the results are obtained, or generally, how the organizational mechanisms operate. With regards to the aforementioned, the organizational mechanism is analysed through the approach to the system of integrated control of the open system of social and economic integration (based on the interests of the stakeholders and interdepartmental cooperation) in the rural areas, where the stakeholders formulate the common objectives of the sustainable development of the rural areas by allocating the available resources, performing particular functions, ensuring transparency of the planning and decision-making processes, setting up and realizing the integrated strategies of development of the rural areas, mutual understanding of the stakeholders and responsibility. Sustainable development of the rural areas depends on the available resources, where the society is able to freely use information, social and institutional mechanisms ensuring feedback, and at the same time on the activities of the institutions, application of advanced technologies, and the competitive ability of the local goods and services. In order to achieve sustainable development it is necessary to harmonize the resources (economic, environmental, social and cultural) of the rural areas, which require an integrated approach and action of the stakeholders seeking to find a compromise between the different elements of sustainability. Therefore, we arrive at the necessity of implementation of the organization mechanism seeking to effectively combine the interests and needs of different actors, prepare and implement integrated strategies and seek sustainability in the rural areas.

Object of the research - elements of the organizational mechanism of development in rural areas.

Aim of the research - to substantiate the conceptual organizational mechanism of development in rural areas, where one of the most important factors with the strongest effect on functionality, i.e. the driving force, is institutional environment of the region.

Copyright (C) 2015 The Authors. Published by Aleksandras Stulginskis University. This is an open-access article distributed under the terms of the Creative Commons Attribution License (CC-BY 4.0), which permits unrestricted use, distribution, and reproduction in any medium, provided the original author and source are credited. 
Tasks of the research: 1) To define the concept "organizational mechanism of rural areas development"; 2) To establish the main elements and processes of the organizational mechanism of development in rural areas; 3) To reveal the characteristics of the rural development models explaining interests of the stakeholders.

\section{RESEARCH METHODOLOGY}

The scientific literature by E. Ostrom (2000, 2005), P. Mahcamer, et al. (2000), P. J. J. Anderson, et al. (2006), A. G. Raišienė (2008), K. Pajunen (2008), E. Rybakovas (2009), P. Zakarevičius (2010), B. Dalal-Clayton, S. Bass (2012) and others were studied applying the following methods: logical, abstraction, comparison, content analysis, collation. While using conceptual units frequency of keyword usage was counted, various text elements connections between one another and whole scope of information were investigated. While using comparison method it was identified organization mechanism elements of rural area development, their expression, relations between them, fulfillment of organizational mechanism aim in respect of stakeholder's interests. Defined the concept of "organizational mechanism of rural areas development". While using collation method it was prepared explanatory organizational mechanism model of rural areas development.

\section{DEFINITION OF (ORGANIZATIONAL) MECHANISM}

For the purposes of analysis of the concept of organizational mechanism it should be noted that the concept of mechanism is not new to the social studies: initially, the term "mechanism" appeared in the research based on methodological individualism (Elster, 1989; Stinchcombe, 1991), as well as in the research of scientific realism (Harre, 1985; Little, 1991) and critical realism (Bhaskar, 1978; Reed, 2001). However, in the past years the concept of mechanism is being used in a number of different scientific researches seeking to explain organizational changes. The mechanisms were analyzed through the prism of various processes: as learning mechanisms (Levinthaland March, 1993); as mechanisms that drive organization to disharmony and to the construction of new harmony (Lamberg and Pajunen, 2005); as blocking mechanisms that prevent change (Chikudate, 1999); and as mechanisms of trust and networked reputation as drivers of competitiveness (Glücklerand and Armbrüster, 2003). Researchers have also underlined the overall need for mechanism-based theorization (Anderson, et al, 2006) and importance of empirical research in seeking to study the causation of the elements of the organizational mechanisms (Pajunen, 2005).

Scientific literature presents the following approaches to the (organizational) mechanism - action organized in such a way as to continuously cause recurrence of the beginning and end (Machamer et al., 2000); mechanisms are processes, which explain causation between the variables (Campbell, 2002); a mechanism for behavior is a complex system, where the interactions between parts can be characterized by direct, invariant, change-relating generalization (Glennan, 2002); a mechanism is characterized as a structure performing a function in virtue of its component parts, component operations, and their organization (Bechtel, Abrahamsen 2005); mechanisms make it possible to explain how separate individuals are able to achieve joint action (Anderson et al., 2006); organizational mechanism can be understood as creation of organizational culture (field of relationships), its realization and nurturing (Šimanskienè and Tarasevičius, 2010); an organizational mechanism is a means of coordination of the organization's activities providing information to the stakeholders, who persuade the public to act in a certain way or cause change in the environment (Esparcia, 2011), etc.

The presented definitions of (organizational) mechanisms allow making an assumption that the description of the organizational mechanism itself requires explanation of the elements it comprises, the causation between the elements, the processes involved, and the functions performed in order to achieve results and changes to the environment.

\section{THE MAIN ELEMENTS AND PROCESSES OF THE ORGANIZATIONAL MECHANISM OF RURAL AREAS DEVELOPMENT}

According to P. Zakarevičius (2010), it is advisable to analyse the organizational mechanism as a particular organizational form, where an organization is understood as a particular system. A mechanism in a social system can be characterized as rotating gear wheels, which explains why one element couples with the other and back, how the elements interact with each other, and what are their connections (Anderson et al., 2006). Following the logic of P. Zakarevičius (2010) that the activities of an organization are based on implementation of the objectives, we can assume that the functions performed by an organization in its activities are the expression of realization of the objectives. It is important that during the performance of the functions a clear sequence of actions is established, i.e. the process of an activity become a function's practical result. Since in an organization, functions and activity processes are connected to each other, we arrive at the following chain: aim - function - process - result. In accordance with the aforementioned chain, the organizational mechanism of rural areas development comprises the following elements (Figure 1. Organizational mechanism of rural areas development):

1. Aim - sustainable development of rural areas;

2. Functions of rural areas;

3. Process - preparation and implementation integrated development strategies of the rural areas;

4. Result - social welfare. 


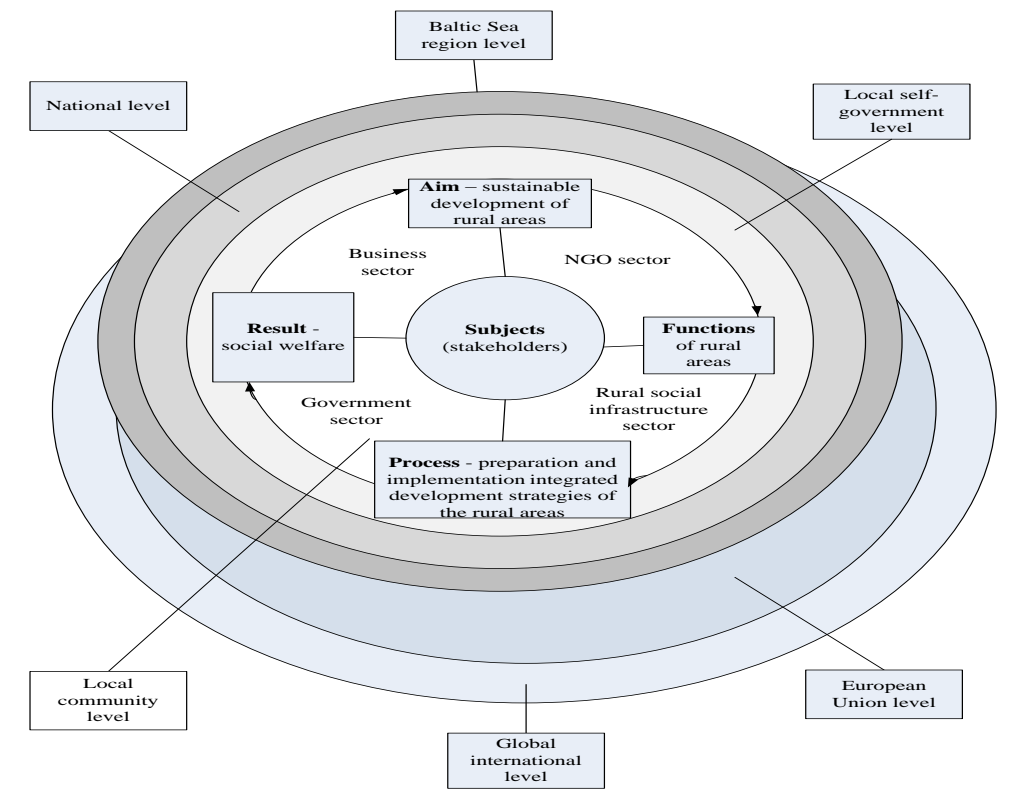

Figure 1. Organizational mechanism of rural areas development (according to Ostrom, 2000, 2005; Mahcamer et al., 2000; Anderson, et al., 2006; Raišienè, 2008; Pajunen, 2008; Rybakovas, 2009; Zakarevičius, 2010; Dalal-Clayton, Bass, 2012).

P. Mahcamer et al. (2006) emphasize that an exceptional feature of the organizational mechanism is the stakeholders (subjects) comprising it, and their actions and behavior. The actions affect the change of environment, while the stakeholders perform certain roles in seeking the change of environment, i.e. a specific result. Otherwise speaking, the stakeholders with a specific aim seek results by performing respective functions and processes. According to K. Pajunen (2008), depending on an organizational mechanism, the specter of the stakeholders can be rather wide - from a particular individual (head or owner of a company, a member of a community, etc.) to respective institutions (ministry, NGO, sector of rural social infrastructure, etc.). The stakeholders are individuals or groups, whose interests or actions are related to current problems, who are interested in a change, control the respective information and resources, and whose support is necessary in seeking to implement the changes (Aligica, 2006). It is important to correctly methodologically identify and analyse the stakeholders and their interests (Table 1). According to the motives the stakeholders are driven by to maintain the connection with the organizational mechanism, their objectives and gain they seek to obtain during cooperation, etc. they can be divided into primary (stakeholders, who are directly, both in a positive and negative way, influenced by the problematic issues, e. g.: farmers, residents of rural areas, children) and secondary (intermediaries of the processes taking place inside the organizational mechanism of development in the rural areas, e. g.: NGO, Government, etc.) (Dalal-Clayton and Bass, 2012).

Table 1. Ways and methodologies for identifying stakeholders.

\begin{tabular}{|c|c|}
\hline WAYS TO IDENTIFY STAKEHOLDERS & $\begin{array}{l}\text { METHODOLOGIES FOR IDENTIFYING STAKEHOLDERS' } \\
\text { INTERESTS, THEIR RELATIONSHIPS AND POWERS }\end{array}$ \\
\hline $\begin{array}{l}\text { Identification by staff of key agencies, and other } \\
\text { knowledgeable individuals }\end{array}$ & $\begin{array}{ll}> & \text { Brainstorming } \\
> & \text { Semi-structured interviews } \\
> & \text { Digging up existing data } \\
> & \text { Time lines } \\
> & \text { Diagrams } \\
> & \text { Sustainable livelihoods analysis }\end{array}$ \\
\hline
\end{tabular}

Adopted from Dalal-Clayton, Bass, 2012.

According to the father of the stakeholder theory E. R. Freeman (1984), in each organization an individual or a group of stakeholders affect the pursuit of the organization's aims. Interests of the stakeholders are twofold, able to bring both benefits and damages, and both rights and duties (Freeman, 2001). D. Susniene and P. Vanagas (2007) emphasize that each organization has stakeholders or groups of them. The stakeholders can be both inside an organization and outside of it, however, their interests are closely related to the prosperity of an organization. They share a common risk of gain or loss as a result of the process activities in an organization. The stakeholder theory substantiates organizational processes by moral and value positions allowing determining the processes of activities of the organizational mechanism. The concept of stakeholders in an organization means that advantageous relationship and connection to the stakeholders (both internally and externally) is an important asset creating current value in an organization and granting opportunities to create value in the future. The stakeholder theory creates conditions for cohesion of elements and processes of the 
organizational mechanism, and explains the relationship between the subjects of an organizational mechanism (Donaldson and Lee, 1995; Damak-Ayadi, Pesqueux, 2005).

Actions of the stakeholders can be individualized according to the qualities of the stakeholders or their methods of action. The key aspect of a productive organizational mechanism is coordinated interaction among the elements of the mechanism. Both the activities of the stakeholders and interaction among the composite parts (elements) of the mechanism must be analyzed as a whole, seeking to underline the activity of each element. Active stakeholder becomes a composite part of the mechanism, otherwise speaking, performs a certain function of the mechanism. This way the elements activate the mechanism, and together create a respective outcome. In general, every element of the organizational mechanism has its own role in achieving a particular result. Elements of the organizational mechanism of development of rural areas cannot be isolated from each other. On the contrary, the activity of elements of the organizational mechanism, their number, capacity and relations become the basis for productive activities of the organizational mechanism of development of the rural areas, and formulate interdepartmental cooperation (Pajunen, 2008). The wider the possibility for realization of interorganizational aims in an organization, the closer the organizational connection formed within an organization. Interorganizational interaction helps to unite the capacities (resources and efforts) of different subjects seeking implementation of complex objectives by skipping over the competence boundaries of several organizations. The form of interaction changes with its intensity: as the volume of common resources and the level of mutual trust of the subject increases. The closer the interaction, the better the expected results of the interorganizational activities (Raišienė, 2008).

"The main idea behind the development initiatives based on interests (as main driving force) of the stakeholders is that their success and effectiveness must guarantee that the actors, who identify their aims with the development objectives and relate them to the development objectives, will be motivated to contribute to such development initiatives, support and participate in them - simultaneously seeking both their individual objectives and common objectives of the social and economic system at the regional level" (Rybakovas, 2009). Collective actions (e. g.: social movements, organizational decisions, etc.) are first of all evaluated through individual actions by relating them to the collective ones.

Any social system comprises two constituents: stakeholders and resources controlled by the stakeholders. Relationship between the system of the stakeholders and resources is realized through their control and interests. If the stakeholders are lacking resources to satisfy their interests, they try to create social connections (cooperation) with other actors with available resources in order to satisfy their interests. Therefore, according to J. S. Coleman (2000), in the socioeconomic system interests can be analysed only in combination with resources, which is a mandatory condition for existence of interests. According to E. Rybakovas (2009), seeking common objective of development may involve investment of different resources of the stakeholders: money, knowledge, time, social connections, labour force, material values, etc.

According to J. S. Coleman (2000), the main driving force of the stakeholders is actions aiding maximum realization of the interests. Principle of maximization is greatly related to resorting to control over the resources. Redistribution of certain actions and control over resources may yield optimal outcomes (e. g.: public/social control of private resources). This way the stakeholders are personally involved in the control processes of resources, which they consider rather important. Exchange happening in the social system allows to achieve maximum overall satisfaction, because personal interests are satisfied at the same time. According to E. Ostrom (2000), personally disinterested actors can contribute to creating public value only in such cases when: the group of actors is very small, actions are related to coercion or other motives related to common interests.

Participation of stakeholders in the organizational mechanism can be either vertical or horizontal. Horizontal participation attempts to ensure that the problematic issues are being solved in different groups of stakeholders (ministries, communities, etc.) Most attention is devoted to non-official organization and mutual interaction. Activity processes are coordinated through cooperation. The stakeholders have clear objectives, are motivated and have a possibility to express their opinion. Communication is clear and transparent, and is not hierarchy-dependent. Regular and objective assessment of results and objectives allows for timely reaction to changes, new challenges and problems arising in the course of the process (Secretary..., 2012). Horizontal mechanism is has an overlapping structure (e. g.: stakeholders and their activities) and are non-structural formations, which are designed to alleviate cooperation in the overlapping areas. The purpose of these mechanisms is to eliminate the obstacles in the inter-institutional cooperation, which emerge as a result of hierarchical accountability.

Through the use of vertical participation, the problems are solved on all the hierarchical levels of decision-making - from national to local level, from leaders to marginal groups. According to M. Bileišis (2012): "when various management models are accepted on the bases of large-volume methodologies, the mechanism consolidates the principle of hierarchy as well." The deeper the "vertical" cooperation, the better the grip of the problem and the more effective the solution process. Even when the agreement between different stakeholders is achieved, its implementation may be rather complex due to political circumstances, where there are no social relations between the political elite and the local layer. Therefore, the important role falls on the local community level, because cooperation on the local level provides a considerable amount of useful information and drives towards institutional changes (Dalal-Clayton and Bass, 2012).

According to E. Ostrom (2000), the main principles can be distinguished, observing which will lead to institutional long-term cooperation based on rules, and harmonious functioning of the organizational mechanism of development of the rural areas: 
1) The first principle involved presence of clear regulations. The stakeholder should know who they cooperate with and whose interests are involved.

2) The second principle is where the local regulations of rural areas limit the amount of resources, time and technological costs in comparison to public resources, allocating the value proportionally to the input of efforts and prepares to accept the local conditions.

3) The third principle includes participation of the stakeholders in determining and modifying the rules, which simplifies collective decision-making.

4) The fourth principle is where the long-term socio-economic system selects own monitoring methods, which involve reporting to stakeholders.

5) The fifth principle is where the socio-economic system uses sanctions depending on the gravity of violations.

Sustainable development of rural areas depends on local resources, where the public is able to freely use information, social and institutional mechanisms, which ensure feedback (Jepson, 2004), and on the activities of an institution. Focus here is on non-formal institutions, which emphasize customs, traditions and norms of social conduct, and on formal institutions, where the activities are based on the laws and specific rules, while the activities and structure are based on regulatory documents (Domarkas et al., 2012). Use of advanced technologies and competitiveness of local goods and services should also be emphasized (Jasaitis, 2006). When striving towards sustainable development of rural areas focus should be placed on the resources of rural areas (economic, environmental, social and cultural), which requires an integrated approach and actions of the stakeholders in seeking to find a compromise between different elements of sustainability.

According to E. Ostrom (2005), the aforementioned principles allow to construct a mechanism of actions comprising seven basic variables. Variables depend on a particular type of an institution - social norms and rules, which define the variables, in any system (Table 2).

Table 2. The elements of the institutional setting of the social system.

\begin{tabular}{|l|l|}
\hline Institutions & Variables of social system \\
\hline Boundary rules & The set of the participants \\
\hline Position rules & The positions to be filed by participants \\
\hline Choice rules & The set of allowable actions and functions that maps actions into realized outcomes \\
\hline Aggregation rules & The control that a participant has over other participants and their decisions \\
\hline Scope rules & The potential (planed) outcomes \\
\hline Information rules & The information available to participants about actions and outcomes and their linkages \\
\hline Payoff rules & Costs and benefits, assigned to actions and outcomes, of participation in the system. \\
\hline
\end{tabular}

The stakeholders perform all the actions, which are attributed to specific positions, the outcomes are related to functions and processes, information is obtained through the relationship between the results and performed functions, control is exercised through the relationship between the results and performed functions, and costs and benefits are calculated through the relationship between the results and performed functions. According to P. Zakarevičius (2010), the main element of regulation of organization's activities is a decision. Therefore, decisions are prepared, adopted and implemented by performing the functions in an organization. Otherwise speaking, the practical outcome of a function becomes the activity process - preparation and implementation of integrated strategies for development in rural areas.

The following functions of the organizational mechanism of development of rural areas can be distinguished

(Dalal-Clayton and Bass, 2012):

1) Communication and educating the public on the issues of sustainable development;

2) Participation in sustainable development actions and debates;

3) Problem analysis and evaluation;

4) Conflict management and negotiations leading to sustainability;

5) Establishing priorities of rural areas;

6) Financial appropriation, distribution and investment into sustainable development of rural areas;

7) Integration of sustainability aspect into the areas raising concern;

8) Coordination of actions;

9) Strengthening of abilities;

10) Delegation of authorizations;

11) Implementation of information system;

12) Monitoring, learning and accountability;

13) Etc.

The purpose of the organization mechanism of rural areas is sustainable development, implementing of which will lead to achieving the outcome of the organization mechanism of rural areas development - social welfare. According to R. Čiegis (2009), the concept of sustainable development is rather wide and in certain cases includes ecological, institutional, cultural and ethical aspects, which become equivalent to the basic ones: economic, environmental and social elements of sustainable development. In other words, sustainable development can be characterized as a combination of environmental protection, economic and social development, the purpose of which is achieving public prosperity outcomes for the present and future generations. Economic development must satisfy the developmental and environmental needs of the present and future generations. Environmental protection cannot be viewed separately from the general development process when seeking sustainable development, while it is best to solve the environmental 
problems, when all the stakeholders participate on the respective level (Agenda 21..., 2001). Adopting and implementing decisions on developmental management of the area according to the principle of sustainable development creates the following conditions: harmonization of interests of inherently different stakeholders of the organizational mechanism to leave no conflicting interests, but joined by a common long-term objective of development of the area; economic development does not produce any negative effect on the environment and human health, while natural resources are used rationally by preserving natural biological variety and reducing environmental pollution. Non-implementation of the conditions of sustainable development will allow the globalization processes to lead to decreasing tendencies of social welfare: sustainable development is not secured in relation to all social groups, social disjuncture is growing, and citizen loyalty to the state is decreasing. Seeking to ensure social wellbeing, the processes of the organizational mechanism of rural areas development must be based on values of professionalism, social trust, civil consciousness, sociality and responsibility (Guogis, Urvikis, 2011). Effective organizational mechanism is possible only in the presence of a good interaction among the civil society, individual entities, private sector and governmental institutions (Domarkas, 2005).

The analysis of the basic elements of the organizational mechanism of rural areas development leads to the definition of the concept of organizational mechanism of rural areas development: Implementation of organizational mechanism for sustainable development in the context of rural areas comprises a complex of individual and collective decisions of the actors of rural development and actions organized to lead to behavioral interaction and sustainability of rural development.

\section{CONCLUSIONS}

1. The analysis of definitions of (organizational) mechanisms allow to make an assumption that the description of the organizational mechanism itself requires explanation of its components, i.e. kind of elements it is composed of, the causation between the elements, the processes involved and the functions performed in order to achieve results and changes to the environment.

2. The organizational mechanism of rural areas development is advisable to analyse as a particular organizational form, where functions and activity processes are connected to each other, creating the following chain: aim-sustainable development of rural areas - functions of rural areas - process - preparation and implementation integrated in development strategies of the rural areas - result - social welfare.

3. The exceptional feature of the organizational mechanism is the stakeholders (subjects) comprising it and their actions. Stakeholders perform certain roles, which affect the change of environment, in seeking the specific result. In this way, organizational mechanism of rural areas development is implemented. Thus, the chain: aim - function - process - result, is activated. Stakeholders with a specific aim seek results by performing respective functions and processes.

4. In the organizational mechanism of rural areas development stakeholders affect the pursuit of the organizational mechanism's aims. Sustainable development of rural areas focus should be placed on the resources of rural areas (economic, environmental, social and cultural), which requires an integrated approach and actions of the stakeholders in seeking to find a compromise between different elements of sustainability.

5. According to the research, provided concept of organizational mechanism of rural areas development is: implementation of organizational mechanism for sustainable development in the context of rural areas comprises a complex of individual and collective decisions of the actors of rural development and actions organized to lead to behavioral interaction and sustainability of rural development.

\section{REFERENCES}

1. Aligica, P. D. 2006. Institutional and stakeholder mapping: frameworks for policy analysis and institutional change. Public organizational review, Vol. 6, Iss. 1, pp. 79-90. http://dx.doi.org/10.1007/s11115-006-6833-0

2. Anderson, P. J. J., Blatt, R., Christianson, M. K., Grant, A. M., Marquis, Ch., Neuman, E. J., Sonenshein, S., Sutcliffe, K. M. 2006. Understanding Mechanisms in Organizational Research. Reflections From a Collective Journey. Journal of management inquiry, Vol. 15, No. 2, pp. 102-113. http://dx.doi.org/10.1177/1056492605280231

3. Bechtel, W., Abrahamsen, A. 2005. Explanation: A mechanist alternative. Studies in history and philosophy of biological and biomedical sciences, Vol. 36, pp. 421-441.

4. Secretary of Baltic cities union of environment and sustainable development. Common planning while seeking better life quality integrated management manager of urban and rural interaction. 2012.

5. Bhaskar, R. 1978. A realist theory of science, $2^{\text {nd }}$ ed. Harvester, Hassocks.

6. Bileišis, M. 2012. Viešasis valdymas ar valdysena? Lietuviškasis kontekstas. (Governance or "governance"? The Lithuanian context). Viešoji politika ir administravimas (Public policy and administration), Vol. 11, Iss. 2, pp. 314-330.

7. Campbell J. L. 2002. Where do we stand? Common mechanisms in organizations and social movements research. Available at: http://webuser.bus.umich.edu/Organizations/smo/protected/resources/2002/wherestand.pdf (accessed on 10/08/2015)

8. Chikudate N. 1999. The state of collective myopia in Japanese business communities: A phenomenological study for exploring blocking mechanisms for change. Journal of management studies, Vol. 36, Iss. 1, pp. 69 - 86. http://dx.doi.org/10.1111/1467-6486.00126

9. Coleman, J. S. 1994. Foundations of social theory, $1^{\text {st }}$ ed., Harvard University Press, Harvard. London.

10. Čiegis, R. 2009. Darnaus žemès ūkio plètra Lietuvoje. (Development of sustainable agriculture in Lithuania). Management theory and studies for rural business and infrastructure development, Vol. 16, pp. 30-37. 
11. Dalal-Clayton, B., Bass, S. 2012. Sustainable development strategies - a resource book, $3^{\text {rd }}$ ed., Routledge, London.

12. Damak-Ayadi, S., Pesqueux, Y. 2005. Stakeholder theory in perspective. Corporate Governance, Vol.5, Iss. 2, pp.5-21. http://dx.doi.org/10.1108/14720700510562622

13. Domarkas, V. 2005. Viešojo administravimo raidos aktualijos. (Core themes of contemporary public administration). (Public policy and administration). Viešoji politika ir administravimas, No. 13, pp. 7-14. (In Lituanian)

14. Domarkas, V., Juknevičienè, V., Kareivaite, R. 2012. Institucinès dimensijos vaidmuo darnaus vystymosi koncepcijoje. (The Role of Institutional Dimension in the Conception of the Sustainable Development). Viešoji politika ir administravimas (Public policy and administration), Vol. 11, No. 3, pp. 461-472. (In Lituanian)

15. Donaldson, T., Lee, P. 1995. The stakeholder theory of the corporation: concepts, evidence and implications. Academy of Management Review, Vol. 20, Iss. 1, pp. 65-91.

16. Elster, J. 1989. Nuts and bolts for the social sciences, Cambridge University Press, Cambridge. http://dx.doi.org/10.1017/CBO9780511812255

17. Esparcia, S., Centeno, R., Hermoso, R., Argente, E. 2011. Artifacting and regulating the environment of a virtual organization. 23rd IEEE International Conference on tools with artificial intelligence, Florida, USA, pp. 547 - 554.

18. Freeman, E. R. 2001. Stakeholder Theory of the Modern Corporation. Perspectives in Business Ethics Sie 3.

19. Freeman, E. R. 2010. Strategic management: a stakeholder approach, 2rd ed., Cambridge University Press, Cambridge. http://dx.doi.org/10.1017/CBO9781139192675

20. Glennan, S. Modeling mechanisms. Studies in history and philosophy of science part C: studies in history and philosophy of biological and biomedical sciences, Vol. 36, Iss. 2, pp. 375-388. http://dx.doi.org/10.1016/j.shpsc.2005.03.011

21. Glückler, J., Armbrüster, T. 2003. Bridging uncertainty in management consulting: The mechanisms of trust and networked reputation. Organization Studies, Vol. 24, No. 2, pp. 269-297. http://dx.doi.org/10.1177/0170840603242004

22. Guogis, A., Urvikis, M. 2011. Socialinè gerovè, naujoji viešoji vadyba ir naujasis viešasis valdymas: šiuolaikiniai iššūkiai. (Social welfare, new public management and new public governance: contemporary challenges). Viešasis administravimas (Public administration), Vol. 31, No 3, pp. 77-87. (In Lituanian)

23. Harre, R. 1985. The philosophies of science, 2nd ed. Oxford University Press, Oxford.

24. Jasaitis, J. 2006. Kaimo raidos tyrimų kompleksiškumo problema. (Complexity of researches on rural development). Ekonomika ir vadyba: aktualijos ir perspektyvos, No 1(6), pp. 87-95. (In Lituanian)

25. Jepson, E. J. 2004. Human Nature and Sustainable Development: A Strategic Challenge for Planners. Journal of Planning Literature, Vol. 19, No. 1, pp. 3-15. http://dx.doi.org/10.1177/0885412204264529

26. Lamberg, J. A., Pajunen K. 2005. Beyond the metaphor: The morphology of organizational decline and turnaround. Human relations, Vol. 58, No. 8, pp. 947-980. http://dx.doi.org/10.1177/0018726705058499

27. Levinthal, D. A., and March J. G. 1993. The myopia of learning. Strategic Management Journal, Vol. 14, Iss. S2, pp. $95-112$. http://dx.doi.org/10.1002/smj.4250141009

28. Little, D. 1991. Varieties of social explanation: An introduction to the philosophy of social sciences. CO: Westview Press, Boulder.

29. LR Aplinkos ministerija. 2001. (Agenda 21). Darbotvarkè 21: subalansuotos plètros veiksmų programa, Rio deklaracija: apie aplinką ir plètrą, miškininkystès principai. Available at: http://www.am.lt/LSP/files/Agenda21.pdf (accessed on 10/08/2015)

30. Machamer, P., Darden, L., Craver, C. F. 2000. Thinking about Mechanisms. Philosophy of Science 67 (1), pp. 1-25. http://dx.doi.org/10.1086/392759

31. Ostrom, E. 2000. Collective action and the evolution of the social norms. Journal of Economic Perspectives, Vol. 14, No. 3, pp. 137-158. http://dx.doi.org/10.1257/jep.14.3.137

32. Ostrom, E. 2005. Understanding institutional diversity. Princeton University Press, Princeton.

33. Pajunen, K. 2008. The Nature of Organizational Mechanisms. Organization Studies, Vol. 29, No. 11, pp. 1449-1468. http://dx.doi.org/10.1177/0170840607096384

34. Raišienè, A. G. 2008. Tarporganizacinès sąveikos turinys lietuvos vietos savivaldos praktikų požiūriu. (Local government servants' attitude towards the content of the inter-organizational interaction). Jurisprudencija, No. 4(106), pp. 50-60. (In Lituanian)

35. Reed, M. 2001 Organization, trust and control: A realist analysis. Organization Studies, Vol. 22, No. 2, p. $201-228$. http://dx.doi.org/10.1177/0170840601222002

36. Romano, D. 1996. Fifth Joint Conference on Agriculture, Food, and the Environment. Session II: Agricultural policy and sustainable development I. Paper 2: Endogenous rural development and sustainability: a European (non orthodox) perspective. Working Paper WP96-4. Center for International Food and Agricultural Policy, University of Minnesota.

37. Rybakovas, E. 2009. A novel approach of the driving forces of socio-economic regional development. Socialiniai mokslai, No. 1(63), pp. 15-27.

38. Stinchcombe, A. L. 1991. The conditions of fruitfulness of theorizing about mechanisms in social science. Philosophy of the Social Sciences, Vol. 21, No. 3, pp. 367-388. http://dx.doi.org/10.1177/004839319102100305

39. Susnienė, D., Vanagas, P. 2007. Means for satisfaction of stakeholders' needs and interests. Engineering Economics, Vol. 55, No. 5, pp. 24-28.

40. Šimanskienè, L., Tarasevičius, T. 2010. Organizacinès kultūros ir vadovų tipų sąsajos. (The relationship between organizational culture and manager's type). Management theory and studies for rural business and infrastructure development, No. 20(1), pp. 138-145. (In Lituanian)

1. Zakarevičius, P. 2010. Organizacijos veiklos procesų valdymas. (Management of organization's activity processes). Organizaciju vadyba: sisteminiai tyrimai, No. 56, pp. 123-132. 